Int. J. Speleol. 10 (1978), pp. 179 - 183

\title{
The occurrence of Metacyclops subdolus Kiefer (Crustacea: Copepoda) in subterranean waters of Greece with remarks on its systematic status.
}

by

\author{
GIUSEPPE LUCIO PESCE (1)
}

In the course of biological studies on the underground aquatic systems of Greece, carried out during 1974-1978 at the Zoological Institutes of the University of L'Aquila and Rome (Italy), besides other subterranean Crustaceans (Amphipods, Isopods, Syncarids, etc.), large samples of Cyclopids Copepods were obtained (Pesce and coll., 1978; Maggi and Pesce, 1978).

Among these materials, which were submitted to me for study, numerous specimens of the supposedly rare and still doubtful hypogean species Metacyclops subdolus Kiefer were identified from samples of Attica and of the Island of Crete.(2)

These records are noteworthy and of great systematic and biogeographic value, since until now this species was reported only from the type-locality, i.e. from the lightly brackish waters of the "L'Abisso», «Buco dei Diavoli» and «Zinzulusa» Caves, Otranteland, Southern Italy. Since 1938, when it was for the first time discovered by Stammer and described by Kiefer, M. subdolus has never been collected either from the type-locality or from other localities, and in the past some doubts were raised about its systematic validity (Ruffo, 1955; Pesce and coll., 1978). The present collections from subterranean freshwaters of Greece, together with some other samples of the same species we recently obtained during our studies, still in progress, from the phreatic waters of the Southern Italy, type locality included (Pesce and coll., 1978), both enlarges its geographical range and helps to better define its systematic status and ecology.

In the present paper, the new localities from Greece together with the main morphological and ecological features of the species are reported and briefly discussed and some remarks on its variability are demonstrated.

(1) Zoological Institute of the University of L'Aquila, Italy. 


\section{Metacyclops subdolus Kiefer 1938}

\section{Material examined}

3 oQ, 1 ? and some copepodites IV, V from a fresh-water well (station n. 1/Cr.) near Ag. Nicholaos, Island of Crete (Greece), 14 July 1974, coll. R. Argano and L. Boitani; numerous $q Q, \sigma^{\top} \sigma^{\top}$ and copepodites III, IV from a freshwater well (station n. G/94) along the Old Road Corinth-Athens, near Ag. Theodoris (Southern Greece), 2 April 1978, coll. G.L. Pesce, D. Maggi and G. Silverii; 15 오오, $35 \overbrace{}^{\top} \nearrow^{\top}$ and copepodites III, IV, from a fresh-water well (station n. G/96) near Megara, Old Road Corinth-Athens (Southern Greece), 3 April 1978, coll. G.L. Pesce, D. Maggi and G. Silverii.

Materials deposited at the Zoological Institute, University of L'Aquila, Italy (author's collection).

\section{Description}

Body about fusiform and slenderly built as in most species of the genus Metacyclops; length, including furcal rami, not including furcal setae, first and second antennae, 550-700 microns in the females, 490-550 in the males (specimens from Southern Italy being slightly shorter). Genital segments slightly longer than large, other abdominal segments larger than long and without spinules on the posterior margin, except the last one which bears a range of small, short, spinules.

First antennae 11-segmented, the aesthete on the 8th segment reaching about the distal end of the 9th segment.

Second antennae 4-segmented.

Trunk limbs with rami 2-segmented, spine formula of the terminal segment of the exopods: 3443 .

$\mathrm{P}_{1}$ : precoxal plate with two rounded tubercles, without spinules or hairs; endopod 2,1.32-1.48 times as long as wide; the seta wich stands at the base of the endopod 1 reaches about the terminal end of the distal article. The spine on the distal article is slender and about as long as the article.

$\mathrm{P}_{2}-\mathrm{P}_{3}$ : precoxal plate without tubercles, spinules or hairs; endopod 2,1.85-2.01 times as long as wide and armed with an apical spine, shorter than the article.

$\mathrm{P}_{4}$ : precoxal plate without tubercles, spines or hairs; endopod 2 elongate, about 2 times as long as wide, and bearing an apical slender spine wich is about as long as the article.

$\mathrm{P}_{5}$ : the basal segment is assimilated with the thorax and reduced to a slender lateral seta; as in the other species of the genus the apical segment is rather short (1.20-1.33 times as long as wide) and armed with a subapical short spine and an apical slender seta. 

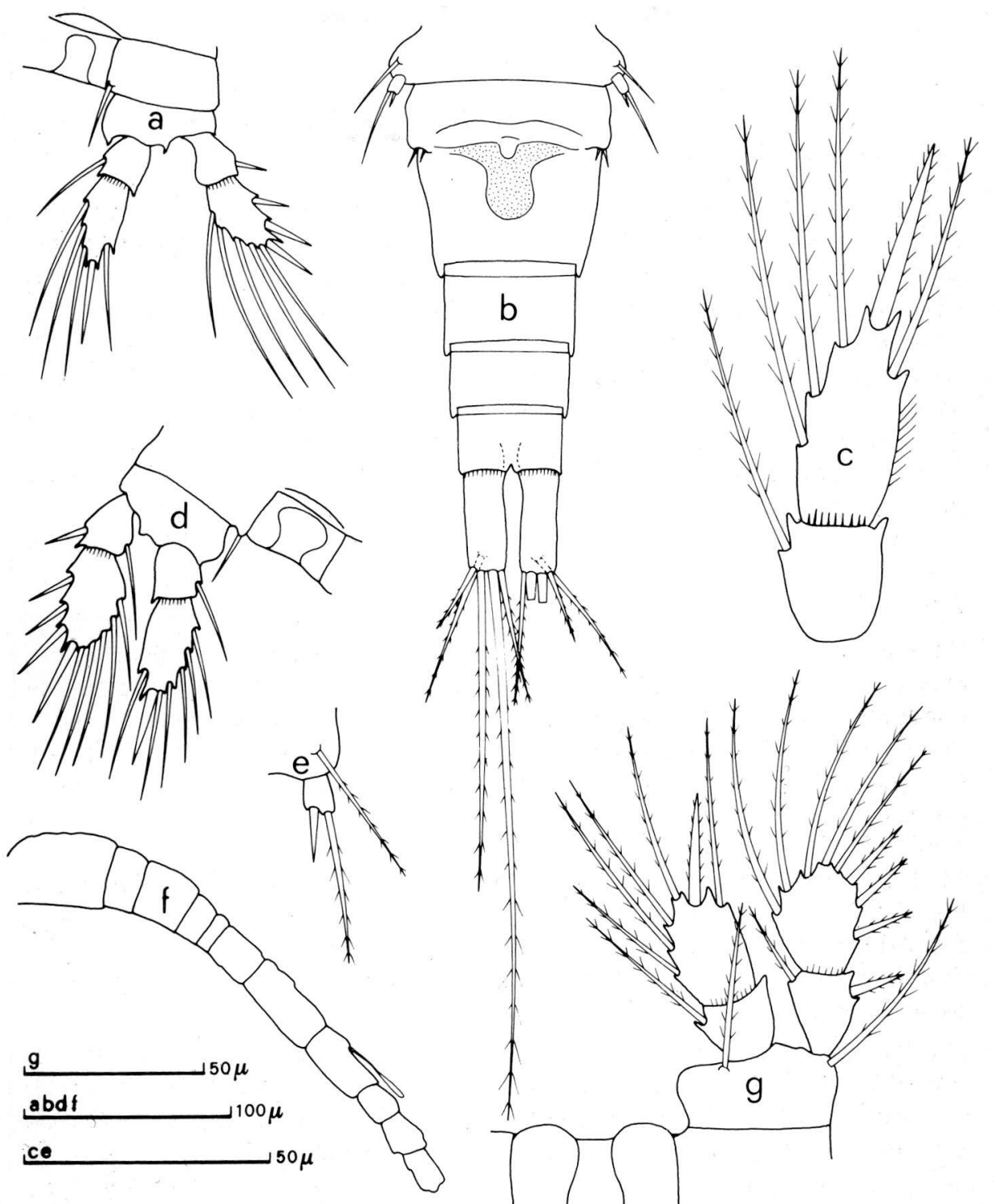

Fig. 1 - Metacyclops subdolus, Island of Crete

a.P4; b.abdomen with furcal rami, ventral view; c.P4, endopod; d.P3; e.P5; f.first antenna; g.P1

$\mathrm{P}_{6}$ :bearing two slender and short (slightly longer in the males) setae, subequal in size.

Furcal rami subparallel, 2.85-3.20 (specimens from Greece)and 3.10-3.39 (specimens from Southern Italy) times longer than wide (wide measured at the level of the lateral setae). Lateral setae inserting at the 2 th terminal half of the 
rami; dorsal seta long and 1.85-2.05 times as long as the outer apical one; inner apical seta longer and about twice the length of the outer apical seta; inner medial seta $1.50-1.70$ as long as the outer medial one.

In the males the furcal rami are slightly longer than in the females both in specimens from Greece and in those from Southern Italy.

\section{REMARKS.}

The specimens of $M$. subdolus from Greece and from Southern Italy and the original description of the species by Kiefer (1938), all agree, except in the following features.(1) The distal article of $\mathrm{P}_{5}$ of the Greek and Italian specimens are slightly longer than large, with ratio L/l constantly more than 1 , compared to the description by Kiefer.(2) The mean ratio between the inner and the outer apical setae of the furcal rami is greater $(2.00-2.15)$ in the specimens from



Fig. 2 - Up to date distribution of Metacyclops subdolus Kiefer 
Greece than in those from Southern Italy and in Kiefer's description (1.78-1.87).(3) The furcal rami are slightly shorter $(\mathrm{L} / 1=2.71-3.01)$ in the Greek specimens than in the Italian ones $(L / 1=3.05-3.36)$.(4) The spine on the distal article of $\mathrm{P}_{4}$ is slightly longer in the specimens from Italy than in those from Greece.(5)The dorsal setae on the furcal rami are longer in the specimens from Italy as compared to those from Greece.

Moreover, the specimens from Southern Italy live in slightly brackish subterranean waters, near the Ionian and Adriatic Sea coasts, while those from Greece were from subterranean fresh-waters.

From all of the above systematic and ecological differences we consider the specimens from Greece and those from Southern Italy as isolated, well differentiated, populations of the same species.

Finally, as far as we know, M.subdolus, once considered endemic to the Salentine Penisula, Southern Italy (Kiefer, 1938; Ruffo, 1955), now has wider distribution and it could regarded, for the present time, as southern transadriatic species. Further researches and records could enlarge and better define the geographical distribution of the species.

\section{RIASSUNTO}

Vengono riportati nuovi dati sulla distribuzione di Metacyclops subdolus Kiefer, specie sino ad oggi ritenuta endemica della Penisola Salentina (Italia Meridionale) e sulla cui validità sistematica erano state già avanzate alcune riserve (Ruffo,1955).

Le nuove raccolte, provenienti da pozzi di acqua dolce della Grecia Meridionale (Attica) e dell'Isola di Creta, vengono confrontate con altre della stessa specie recentemente ottenute dall'Italia Meridionale, compresa la località tipica.

L'A. aggiorna la distribuzione geografica di questa specie come pure definitivamente conferma la sua validità sistematica.

\section{REFERENCES}

KIEFER F., 1938 - Cyclopiden (Crust.Cop.) aus süditalienischen Brunnen und Höhlen. Zool. Anz. 123(1-2):1-12.

MAGGI D., and G.L. PESCE, 1978 - Cyclopides des eaux souterraines phreatiques de la Grèce

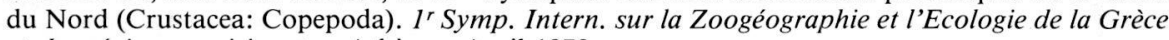
et des régions avoisinantes, Athènes, Avril 1978.

PESCE G.L., R. ARGANO and D. MAGGI, 1978 - Biological researches on the subterranean phreatic waters of Northern Greece Ir Symp. Intern. sur la Zoogéographie et l'Ecologie de la Grèce et des régions avoisinantes, Athènes, Avril, 1978.

PESCE G.L., G. FUSACCHIA, D. MAGGI and P. TETE', 1978 - Ricerche faunistiche in acque freatiche del Salento.(Contributo alla conoscenza della fauna delle acque sotterranee dell'Italia centro-meridionale/V). Thalassia Salentina, 8 (in press).

RUFFO S., 1955 - Le attuali conoscenze sulla fauna cavernicola della regione pugliese. Mem. Biogeogr. Adriatica. 3:1-143. 